Article

\title{
From Active Aging to Active Citizenship: The Role of (Age) Friendliness
}

\author{
Elena del Barrio ${ }^{1, *}$, Sara Marsillas ${ }^{1}$, Tine Buffel $^{2}$, An-Sofie Smetcoren ${ }^{3}$ and Mayte Sancho ${ }^{1}$ \\ 1 Matia Institute, 28020 Madrid, Spain; sara.marsillas@matiafundazioa.eus (S.M.); \\ mayte.sancho@matiafundazioa.eus (M.S.) \\ 2 School of Social Sciences, Manchester Institute for Collaborative Research on Ageing (MICRA), \\ The University of Manchester, Manchester M13 9PL, UK; tine.buffel@manchester.ac.uk \\ 3 Deparment of Educational Science, Vrije Universiteit Brussel, 1050 Brussel, Belgium; \\ An-Sofie.Smetcoren@vub.be \\ * Correspondence: elena.barrio@matiafundazioa.eus
}

Received: 30 March 2018; Accepted: 7 August 2018; Published: 13 August 2018

\begin{abstract}
The concept of 'Active Aging' emerged in the 1990s, reflecting a growing emphasis on the relationships between health, participation, aging, and independence. The concept focuses on encouraging the participation of older adults in society and it recognizes the competence and knowledge that older people possess. The Active Aging discourse developed as a broad political response to demographic aging, one which promotes a cultural shift in what 'old age' may mean, by providing older people with new roles. The initiative "Age-Friendly Cities and Communities", which was launched by the WHO in 2007, was developed with the aim of applying this paradigm into practice at the local level. Its purpose was to promote a movement of citizen participation where older people have a leading role as generators of well-being, and tackling the barriers of Active Aging. This paper provides a theoretical reflection concerning the development of the concept of Active Aging and how this has led to new ways of active citizenship in later life. New generations of older people demand a space where they can develop and contribute to society, regardless of their age. The aging of the population poses challenges and opportunities, which we can and must take advantage of in order to build a better and more egalitarian society, one that recognizes the value of diversity.
\end{abstract}

Keywords: active aging; age-friendly cities; participation; older people; citizenship

\section{Introduction}

Active Aging is defined as 'helping people stay in charge of their own lives for as long as possible as they age, and, where possible, to contribute to the economy and society' (EC 2018). The concept Active Aging was welcomed given its compatibility with others (such as successful, optimal, productive, vital, positive aging; see, (Rowe and Kahn 1998; Baltes and Baltes 1990; for a review see: Fernández-Ballesteros 2008; Fernández-Ballesteros et al. 2011)). It is considered to be embedded in the semantic network of "aging well", reflecting a new paradigm in gerontology—one that challenges deficit models of aging, and emphasizes aging the various roles that older people can play in society. The Active Aging Framework has led to a range of initiatives and programmes across various cities and communities in the world. These are aimed at promoting opportunities for people to continue to participate in social, civic, cultural, and economic aspects of life in old age.

At the same time, we are undergoing a change in the structure of life stages. The three phases that make up a person's life course (learning-youth, work-adulthood, and retirement-aging) were conceptualized in the beginning of the last century and can no longer be applied to contemporary 
society (Komp and Johansson 2016; Prieto et al. 2015; Subirats 2016). The combination of a longer life and other societal changes is reshaping the three-stage life course (ILC 2015). This generation embodies distinct features; they are better educated than any other preceding generation, and there is an activist and rebellious spirit at their core. It is a generation that has fought against racism, homophobia, and political autho-ritarianism, and fought for women's rights, citizen empowerment, and sexual freedom. It is a generation that is comfortable with demanding to be heard (Kalache 2013), and it is reinventing the way older age is lived and viewed (Gilleard 2005). Current generations are increasingly demanding a space where they can develop and contribute to the society, performing a role in which they recognise themselves, not where they are told who they are but a place to remain being themselves (Prieto et al. 2015). The Age-Friendly Cities Project has the potential to develop responses that are aimed at supporting the aspirations of these new generations by promoting a process of citizen participation in improving the welfare of cities (OMS 2007). The Age-Friendly project puts into practice the paradigm of active aging at the local level by focusing on the promotion of active citizenship. In the light of changing generations of older people aspiring active and engaged lives, this paper presents a theoretical reflection about the origins and development of the concept of Active aging and its criticisms. The paper questions whether a new citizen movement is born, ensuing from the emergence of the Age-Friendly Cities program.

\section{Active Aging}

The 'Active Aging' concept firstly emerged during the International Year of Older Persons (1999) in an editorial, written by Kalache (1999), where he established an association between activity on the one hand and opportunities to be healthy in later life on the other. The author highlights the need to create and maintain opportunities for older people to remain active. For the first time and prior to the definition that was proposed by the WHO in 2002, Active Aging was defined as "the process of optimizing opportunities for physical, social, and mental well-being throughout the life course to extend healthy life expectancy" (Kalache 1999, p. 299). This concept was adopted by the WHO to develop a more complete message than healthy aging, as it recognizes other important factors in the aging process beyond health, such as activity and participation (Fernández-Ballesteros 2005; Kalache and Kickbusch 1997; WHO 2002).

The turning point in the focus of the WHO to address the challenge to build a society for all ages took place in the Madrid International Plan of Action on Aging and the Political Declaration adopted at the Second World Assembly on Aging of the United Nations held in 2002. The political framework on Active Aging was presented in this assembly, which gave rise to the emergence of a new political concept that gathered the scientific tradition developed in the last decades of the twentieth century. As a result of this assembly, the document "Active Aging: A Political Framework" (WHO 2002) was published, which was aimed at those in charge of formulating aging policies and programs. It highlights the need for addressing the aging population with the coordination of different agencies to promote Active Aging, defined as "the process of optimizing opportunities for health, participation and security, in order to enhance the quality of life as people age" (p. 12). Three basic pillars are established in this definition to promote Active Aging: participation, health and security, to which a fourth pillar was subsequently added, i.e., lifelong learning (ILC 2015). The aim is that people can develop their full potential of physical, social and mental well-being throughout the life course and participate in society according to their needs, desires and abilities, while providing adequate protection, security, and care when they need assistance (WHO 2002).

The roots of the concept of Active Aging can be traced back to the socio-gerontological literature underlining the importance of an active lifestyle for the attainment of life satisfaction in old age, a theory that developed in the $40 \mathrm{~s}$ and $50 \mathrm{~s}$ known as 'activity theory' (Havighurst 1961). Its emphasis on activity and its association with well-being and life satisfaction has persisted until nowadays (Boudiny 2013; Foster and Walker 2013, 2015; Marsillas et al. 2017). Additionally, Active Aging was developed in line with other concepts associated with the positive paradigm of aging, such as 
'productive' or 'healthy' aging (Marsillas 2016). In terms of the first, influences of productive aging can be detected in definitions of Active Aging, for example, through the emphasis on productive activities as a way of maintaining the pension system and welfare systems in general (Bass et al. 1993; Buys and Miller 2006; Foster and Walker 2013; Mendes 2013; Walker 2002). Secondly, Active Aging has also embraced the concept of healthy aging, by including its emphasis on the promotion and maintenance of health and independence in later life through healthy practices, especially physical activity (Foster and Walker 2013; WHO 2002, 1990). However, the concept of Active Aging aims to overcome the limitations of both the "productive" or "healthy" aging perspective by expanding its sphere of influence to essential dimensions, such as continuous participation in social, economic, cultural, spiritual, and civic issues (WHO 2002).

Despite the multi-dimensionality of the concept, policy debates around Active Aging are often centered around only one dimension, focusing on either economic aspects and questions around employment and extending working lives, or on physical activity as a way to improve health in old age, thus reflecting the previous concepts of productive and healthy aging (Boudiny 2013; Boudiny and Mortelmans 2011; Marsillas 2016). Both conceptualizations are insufficient and reflect a one-dimensional reduction of the concept which explicitly contradicts the WHO's intention and recommendations. Any of these would bring the return of Active Aging to its precursor concepts; therefore, all the effort to create an inclusive concept would be in vain (Boudiny 2013; Boudiny and Mortelmans 2011; Fernández-Ballesteros 2008). At the same time, however, there are also broader conceptions of active aging, these including participation in various domains of life besides economic ones, such as social and leisure activities (Blanco 2010; Fernández-Mayoralas et al. 2015; Sidorenko and Zaidi 2013). In spite of its expansion and importance, the need for a commonly accepted operational definition of Active Aging remains a repeated conclusion in a number of studies (Boudiny 2013; Lassen and Moreira 2014; Marsillas 2016; WHO 2002; Paúl et al. 2012).

\section{Active Aging as a Political Strategy}

Active Aging is not only a scientific construct or an individual concept; it is a complex notion with a key role in the global strategy for the management of aging populations (Stenner et al. 2011; Walker 2009). The policy of Active Aging combines demographic, economic, and social gerontology models to create a new model of old age that is designed to change the mental representations of aging established by social policies of the last decades, by modifying perspectives, stereotypes, and prejudices (Foster and Walker 2015; Lassen and Moreira 2014). Indeed, its meaning cannot be "adequately grasped without understanding that it was created to change our visions, perspectives, understandings, stereotypes and prejudices about aging to reconstruct the practical social reality of the aging process in an 'aging society'” (Stenner et al. 2011, p. 468).

Following the above, the concept of Active Aging has a greater political potential than other discourses of aging, because it is represented as a complete and solid strategy that unifies key political domains, such as employment, pensions, retirement, health, and citizenship (Foster and Walker 2013, 2015; Walker 2002). In 2002, the European Commission defined Active Aging as a coherent strategy to allow for aging well in aging societies, which in practice, means lifelong learning, working longer, retiring later, and more gradually, being active after retirement and engaging in activities to promote skills and maintain health (EC 2002). Nonetheless, this concept is not uniform across European discourses. Two different types of political discourses have been identified, especially after the Lisbon Treaty of 2007 (Walker and Maltby 2012). The first and the most dominant perspective emphasize the productivity approach, focusing almost entirely on employment policies and labor market involvement after retirement age (EC 1999). The second discourse also defends the contribution to society through unpaid work, such as volunteering or the transmission of knowledge to other generations, as well as living autonomously and with dignity for as long as possible (Foster and Walker 2015; Hasmanová 2011). 
In the political sphere, the productivist and economic approach has dominated the debate around Active Aging, suggesting a return to its precursor, i.e., the productive aging paradigm (Boudiny 2013; Bowling 2009; Walker and Maltby 2012). More recent initiatives, however, have begun to acknowledge other dimensions of Active Aging. The European Year of Active Aging and Intergenerational Solidarity (2012), for example, was intended to promote the population's knowledge about aging and to pose solutions to address this challenge, highlighting the need for promoting Active Aging to help people to play a role in society as active citizens, as well as to promote health in aging. In this way, it attempts to foster the principles of participation and empowerment, which are established as facilitators for the achievement of Active Aging objectives (Walker 2002). Therefore, the aim is to promote an active citizenship that defends its options and preferences as well as promotes a more fluid and horizontal communication between society and political areas through participation (Walker 2002).

Even in Europe, the Active Aging framework maintains its supremacy, in the World Report on Aging and Health (WHO 2015) the it has been replaced by the earlier concept of healthy aging, which was defined as "the process of developing and maintaining the functional ability that enables well-being in older age; functional ability comprises the health related attributes that enable people to be and to do what they have reason to value" (p. 41). In doing so, the WHO framework has become more reductionist again, by focusing on healthy aging and functional abilities as well as medicalizing the concepts of health and aging well. In this way, it undoes the progress towards a more comprehensive concept of a good old age represented by Active Aging.

\section{Model and Determinants of Active Aging}

Active Aging integrates activity and participation, representing the core dimensions, along with health, independence and good aging (Van Malderen et al. 2013). The adjective "active" refers to two closely related aspects: first, the activity and second, the ability to be the protagonist of one's life and its aging process (Stenner et al. 2011). The human being is an active agent of his/her own aging, which is built throughout life in interaction with an active world and through a continuous and dynamic process (Bandura 1986; Caprara et al. 2013; Fernández-Ballesteros 2008; WHO 2002). It recognizes that aging is influenced by environmental, economic, cultural, and social conditions of a concrete context, which provides opportunities and resources or creates barriers for older people.

In addition to developing a definition of Active Aging, the WHO (2002) also proposed a theoretical model of the concept. This model suggests that life course trajectories are influenced by different types of determinants that surround people, families, and nations, these including health and social services, behavioral, personal, physical environment, social, and economic determinants. It also highlights that people age in different ways throughout life. The model includes several determinants at a population and individual level that can have an influence on Active Aging and contribute to well-being; all of these influenced by two transversal factors: culture and gender. Personal determinants refer to the individual biological, psychological, and behavioral conditions of aging people. Contextual determinants include socio-economic, socio-political, and environmental factors affecting the environment in which people age. In this model, the physical environment is of great importance and is seen as the main factor in determining people's level of (in)dependency (WHO 2002). Given the major influence of the physical environment, local governments have an important role to play in terms of developing policies and interventions that support the participation of diverse groups of older people in their environment and community. At the same time, older people themselves can, and should be supported to play a crucial role in influencing improving and creating the conditions that favor their aging process and improve their well-being (Foster and Walker 2015; Walker 2002).

Last developments in the field have produced a tool to quantify the Active Aging following the guidelines of health, activity, and autonomy: The Active Aging Index (AAI). This index is the result of a research project managed jointly by the European Commission's Employment, Social Affairs and Inclusion Directorate General and the United Nations Economic Commission for Europe (UNECE). The AAI is a toolkit comprising twenty-two individual indicators grouped in four 
domains: Employment; Social Participation; Independent Living, and Capacity for Active Aging. The development of the AAI tool shows a different way to treat Active Aging. The concept of Active Aging of AAI incorporates an economic dimension that involves the insertion of older persons in the labour market and other productive activities. That transcends the individual perspective to a societal one. Active Aging is "the situation where people are able to live healthy, independent, and secure lives as they age, and thus continue to participate in the formal labour market as well as engage in other unpaid productive activities (such as volunteering and care provision to family members)" (Zaidi et al. 2013, p. 6).

\section{Active Aging: Criticisms}

After this introduction, it may seem that Active Aging is the 'solution'; however it is not free of critiques. First, it the emphasis on employment and productive slope (Boudiny 2013; Foster and Walker 2015; Walker 2009; Walker and Maltby 2012) should be noted, placing employment as the axis of the own identity (Dyk 2014) and creating an implicit obligation to work (Mendes 2013), excluding those people out of the labor market or productive activities, such as volunteering or caring (Boudiny 2013; Boudiny and Mortelmans 2011; Foster and Walker 2013, 2015; Walker 2009).

It can be argued that activities and values within the light of Active Aging are more associated with those that are carried out by more young-old or functionally independent people (Boudiny and Mortelmans 2011; Clarke and Warren 2007; Townsend et al. 2006; Dyk 2014). In contrast, those categorised as 'non active' remain stigmatized (Venn and Arber 2011; Williams et al. 2012). Another source of critical thinking is that the lifestyle promoted in the current discourse of Active Aging is easy to be followed by people who can pay for it, who have the physical or mental ability, and who can participate in the institutions where it is promoted (Biggs 2001; Bowling 2005; Hasmanová 2011). In this way, the Active Aging paradigm is becoming coercive, since the social images promoted are being interiorized by older people (Foster and Walker 2015; Katz 2000; Townsend et al. 2006) with high expectations being placed up on them (Boudiny 2013). Those expectations can be assumed as a challenge or a threat depending on personal circumstances in terms of health, educational level, or income (Pavlova and Silbereisen 2012). In addition, this paradigm is not prepared to incorporate the notion of decline (Foster and Walker 2015; Moulaert and Paris 2013) and it ignores the barriers of certain social groups to meet the ideals of old age (Hasmanová 2011).

Thus, Active Aging may be unattainable for a large group of society, especially those who cannot attend to the ideal of Active Aging, because of lack of resources, or simply because they prefer not to (Holstein and Minkler 2003; Marsillas 2016). This may contribute to social discrimination and the exclusion of the oldest-old, as well as those vulnerable, fragile, and dependent, who do not meet the criteria in terms of health, independence, productivity, and activity (Boudiny 2013; Marsillas 2016; Perek-Białas et al. 2008; Ranzijn 2010; Dyk 2014; Walker 2016).

Despite the theoretical span of the Active Aging concept and its distinctions from related models, such as successful aging (Katz 2005; Mendes 2013; Ranzijn 2010; Dyk 2014; Venn and Arber 2011), in practice, the Active Aging concept is becoming narrower and oppressive (Boudiny 2013; Foster and Walker 2015). Active aging is often associated with an economic or physical framework, by relating the concept to physical exercise on the one hand or employment on the other. In doing this, particular groups of people remain excluded from aging 'actively', such as those vulnerable, functionally limited, or those not engaged in the labour market (Boudiny 2013; Walker 2002). Additionally, this contradicts the principles and intentions of the concept 'Active Aging' (Walker 2002; Foster and Walker 2015). They stipulate that the activity needs to be considered in a broad sense, including all types of activity that contribute to the well-being of older people, families, and the society. Unless changes are made in including new alternative ways to age actively, Active Aging will result in a new categorization of old age, being narrow, oppressive, excluding, and normative, with an excessive idealization of old age (Foster and Walker 2015; Holstein and Minkler 2007; Marsillas 2016) risking 
the same mistakes of activity theory (Boudiny 2013) and successful aging (Pruchno et al. 2010; Strawbridge et al. 2002).

\section{Life Course in the New Generations}

According to Elder (1974), the life course represents the ideal sequence of events that individuals expect to experience and the social positions they expect to occupy as they move forward through life (Barrio 2016). Every society has expectations about the behaviors that correspond to each life stage, in such a way that the individual passes from birth to death through a socially regulated cycle, where status associated with age are related to a series of rights, duties, and specific obligations (Neugarten 1968). In this way, entry into school, initiation into working life, marriage, procreation, retirement, etc., are moments in the life course that imply changes in the sense of identity, since they indicate the acceptance of new social and emotional roles (Barrio 2016).

As the 21st century advances and the longer life courses of individuals are buffeted by a greater complexity of intermingling and sometimes recurring variables, the boundaries of the three-stage life-course model are inevitably going to become even more ill defined (ILC 2015). Even though the three stages have been functional for socioeconomic regulation, they have generated criticisms that are related to social inclusion of older people and have always been problematic from the perspective of the freedom of individuals, understood as autonomy to establish and pursue their own life projects (Seguí-Cosme and Alfageme 2008, p. 391). The vital milestones that divided the different stages no longer serve to distinguish the childhood from youth, the youth from adulthood, or the adulthood from old age (ILC 2015; Subirats 2016). Nonetheless, age differentiation criteria are still being used in a more or less automatic way. Already in 1992, Guillemard considered that the political response to the problem of aging necessarily implied creating a true policy of ages, which would take care of developing the potentialities of each one to organize life and define the alternative of their own activities, in each and every one of the life stages (Guillemard 1992).

Today is defined as a time of "crisis of the institutions", where the stages or ages corresponding to perform areas built previously are no longer exercised as such, or at least not in the same way, diluting their previous forms and marking more winding and less predictable paths (Prieto et al. 2015).

Societies are currently going through a period of transition in which the ages begin to become blurred and the differences "based on age" fade away. Identity is built through lifestyles, daily patterns, leisure, or consumption. Participation must be able to take into account the particular experience of each person, allowing them to find a platform for linking to the world, from where they can play a role in which they are recognized, continuing what they have been throughout their lives (Prieto et al. 2015). The new generation of seniors wants to continue contributing and is willing to integrate into processes with groups and communities that they identify with, independently of their age (Prieto et al. 2015; ILC 2015). Thus, the challenge of society lies in the ability to generate spaces that respond to this search for recognition through shared personal development. The way to rethink this reality needs to start from a full conception of citizenship, in which all people are recognized, whatever their age, gender, or origin (Subirats 2011).

In this sense, the debate on Active Aging takes on another dimension. It is no longer just a question of adapting or accommodating what was done to a new, more complex and integral paradigm. The current debate questions the role of the public power in the new scenario (Subirats 2016). It will be increasingly difficult to talk about the "collective" of older people as something susceptible to being characterized in a more or less homogeneous way. The extremely "liquid" situation (Bauman 1999) of personal trajectories does not allow for continuing with these paradigms (Subirats 2016). The increase in life expectancy, the new technological reality, the change in life and work trajectories, and the differences of cultural identity will require perspectives starting from the recognition of diversity. This recognition assumes the protagonism of older people in the co-production of policies that affect them as well as their empowerment to question and participate in everything that concerns them. Thus, it is necessary to talk about diversified and heterogeneous generational dynamics (Subirats 2016). 


\section{Movement towards Age-Friendliness of the Environments}

Five years after the release of the WHO document defining the concept of Active Aging, the movement of age-friendliness emerged. The initiative "Age-Friendly Cities and Communities" (AFCC) was launched by the WHO in 2007, leading to the Global Network of Age-Friendly Cities and Communities in 2010, aimed at improving the physical and social environments to become better places in which to grow old (WHO 2014). The AFCC initiative has as its general objective to implement the paradigm of Active Aging at the local level (WHO 2007), putting the focus on the promotion of citizen participation of older people. In this way, the program approaches the claims of the new generations of older people, generating a space for participation led by them, but with the aim of improving cities, neighborhoods, or towns for all ages.

\section{Age-Friendly Cities and Communities: Origins}

The first step towards the origin of this project took place in 2003 within the framework of the Age Friendly Primary Health Care Project, which incorporated the perspective of Active Aging (WHO 2004). In this project, the WHO recognized the importance of Primary Care Centers for the health of older people. Additionally, the need for accessible health centers, adapted to the needs of older people, was highlighted, and a series of workshops following the bottom-up methodology with the support of the Australian Government was launched. The results of this qualitative study, reinforced by experts' knowledge, led to the development of a set of Age-Friendly principles for Primary Care Centers (WHO 2004).

One year later, in 2005, Kalache, ideologist and pioneer of the Active Aging movement, launched the Age Friendly City concept in the inaugural session of the XVIII Congress of the International Association of Geriatrics and Gerontology (IAGG) in Rio de Janeiro. At the conference, participants from all over the world from both academic and policy as well as professional fields showed their interest in this idea, and they started to develop work on the intersection between aging and urbanization (Kalache 2016; Barrio et al. 2016).

Population aging and urbanization are identified as among the most significant social trends affecting life in the twenty-first century. They are regarded as central to the economic and social development of cities and countries. Both trends converge in an increasing number and proportion of older people living in urban areas around the world (UN 2011, 2017). The pressures on urban environments suggest significant challenges for policies that are seeking to reconcile population aging with urban development (Buffel and Phillipson 2018a, 2018b). The movement of creating 'age-friendly' environments was developed as a model to provide a response to these challenges, with the main objective to leverage the potential of older citizens (WHO 2007). In order to achieve this, older people are the protagonists of a movement of citizen participation to adapt the services and infrastructure to the cities to accommodate the needs of their aging populations (Kalache 2016; Barrio et al. 2016).

All cities and communities that wish to join the WHO Network must follow methodological guidelines that are based on the Vancouver Protocol and the Global Age-Friendly Cities Guide (WHO 2007). This guide identifies the essential features of an age-friendly city from the perspective of older people and service providers, and it serves as a reference for all types of cities (Plouffe and Kalache 2010; WHO 2007). Additionally, the theory and the areas that compound this concept are included in this document. "In an age-friendly community, policies, services and structures related to the physical and social environment are designed to support and enable older people to "age actively" - that is, to live in security, enjoy good health and continue to participate fully in society"(WHO 2007, 2014).

The WHO initiative spread rapidly and gained acknowledgement as a global movement (Barusch 2013; Golant 2014; Liddle et al. 2014; Lui et al. 2009; Fitzgerald and Caro 2016; Scharlach and Lehning 2013; Moulaert and Garon 2016; Buffel and Phillipson 2018a). Such age-friendly programs bring together a range of partners to address the environmental and social factors that contribute to active and healthy aging. Given that the physical and social environments are key determinants 
for people to stay healthy and independent; building communities responsive to the needs of their older residents is one of the most effective social policy approaches to respond to aging challenges (WHO 2014).

In 2010, the WHO launched the Global Network of Age-Friendly Cities and Communities. Since its launch in 2010, the Network has had a rapid increase in membership, reaching over 600 cities and communities across 38 countries in the Global North and South by January 2018 (WHO 2018). The Network was established to promote the exchange of experience and mutual learning between cities and communities around the world, by creating a global platform that favours the exchange of information as well as accelerating change at a global level. It also offers guidance and promotes the acquisition of knowledge on how to assess the degree of adaptation of a city or community to older people; how to integrate urban planning; and, how to create everyday environments that are responsive to the needs of people as they age (Barrio et al. 2016). The Global Network of Age-Friendly Cities and Communities requires its members to periodically evaluate their policies and action plans aimed at progressively improving the age-friendliness, in order to achieve an urban environment that supports the process of Active Aging. A central idea is that older people should have the opportunity to participate actively in this process, through community participation procedures. The extent to which this is the case, however, significantly varies between different cities and age-friendly initiatives, with programmes using participatory or 'bottom-up' approaches that recognize the central role of older people on the one hand, and models adopting a more 'top-down' or government-led approach on the other (Rémillard-Boilard et al. 2017) (See further below).

In Spain, the Institute of Older People and Social Services (IMSERSO) signed a collaborative agreement with the WHO in 2012 to create an Age-Friendly Ibero-American Network of Cities and Communities that combined all initiatives from Spanish speaking countries. At present, more than 100 cities and municipalities are affiliated to this Network in Spain, being the country with the highest number of members worldwide.

The efforts entailed to make cities and communities more age-friendly have gained significant impetus in recent years. The aging of the population and the increase in urbanization have challenged governments and other organizations to consider the best way to develop communities accessible and inclusive to all (Fitzgerald and Caro 2014).

\section{Aging in Place and Age-Friendly Communities}

The theme "aging in place" was coined at the beginning of the 90s between experts and researchers in the field of gerontology, following the desire that was expressed by older people to remaining living in the community, with some level of independence, rather than in residential care (Davey et al. 2004, p. 133). Following this, international studies on aging began to address a range of issues relating to housing and the environment as fundamental elements for aging well (Wahl et al. 2009). The idea of 'aging in place' as a policy priority has since been widely accepted (Heumann and Bold 1993; Rowles 1993). However, a number of limitations have been identified to achieve this ideal, including pressures that are associated with social protection policies in many countries. In order to advance policies that aim to support the 'aging in place' ideal, it is necessary to work on the development of age-friendly communities (Lui et al. 2009).

An Age-Friendly community can be defined as "a place where older people participate actively, are valued and supported with infrastructures and services that are effectively adapted to their needs" (Alley et al. 2007, p. 4). These communities provide at least two pertinent forms of participation for older residents: in the more basic form, older people are simply active in the life of the community through interaction with other people and using community resources; on the other hand, older people can also participate in political and related organizations within the community. This suggests that communities present opportunities to all residents, including older people, to actively participate in decisions that affect the development of different aspects of a friendly community (Fitzgerald and Caro 2014). 
The growth in popularity of the Age-Friendly movement has contributed to the development of multiple Age-Friendly frameworks and initiatives worldwide. These can be found under a variety of terms in the literature: 'age-friendly', 'aging-friendly', 'liveable', and 'lifetime neighborhoods/communities / cities/environments' (Scharlach and Lehning 2013; Buffel and Phillipson 2018a; Steels 2015). A review of these models found that the emerging ideal framework is characterized by a focus on both the social and physical environment; includes a participatory model of collaborative governance; and, focuses, in particular, on the objective of 'inclusiveness' (Lui et al. 2009). The model envisages a community where older people are not only the beneficiaries, but also have a key role to play in defining and promoting their distinctive Age-Friendly features. The WHO states that one of the essential conditions for creating age-friendly cities and communities is older people's meaningful participation in all stages of the development process (WHO 2017). This last point-where older people are seen as crucial agents of change-is supported by research adopting a participatory approach to involving older people as key actors in researching and developing age-friendly communities (Buffel et al. 2012). Such a collaborative approach, in which older people play a central role as co-researchers in developing Age-Friendly initiatives, has been shown to facilitate community development and change at the local level, which can lead to more hospitable and supportive community environments and to increase civic engagement and social capital (Buffel 2018a). However, further advances must be made in developing strategies to sustain Age-Friendly work as a collective community building process, and in gaining commitments to develop structural solutions with a range of stakeholders.

\section{Citizen Participation and Governance}

The WHO approach to Active Aging details that it is based on the recognition of human rights. In doing so, "it shifts strategic planning away from a "needs-based" approach (which assumes that older people are passive targets) to a "rights-based" approach that recognizes the rights of people to equality of opportunity and treatment in all aspects of life as they grow older. It supports their responsibility to exercise their participation in the political process and other aspects of community life." (WHO 2002).

Despite the radical promise of the WHO formulation of Active Aging and its rhetorical prominence in Europe and worldwide, its actual realization is limited in terms of fully formulated and implemented strategies (Walker 2016). The paradigm of Active Aging has become trivialized by being associated with the broad spectrum of activities that are aimed at older people as a user, consumer, or spectator. Often these more general activities neglect the participation and involvement of older people in decision-making processes (Barrio et al. 2016). Based on the WHO definition (WHO 2002), Walker $(2002,2009)$ proposed seven key principles as the basis for a comprehensive strategy on Active Aging, including the recognition that activity means more than paid work, or that Active Aging must encompass all older people, even those who are frail and dependent. The sixth one specifies that any "strategy on Active Aging should be participative and empowering. In other words, there must be a combination of top-down policy action to enable and motivate activity with, also, opportunities for citizens to take action from the bottom up, for example in developing their own forms of activity" (Walker 2002, p. 125). An effective strategy of Active Aging must be based on the combined contributions of the citizen and society (Foster and Walker 2015). The age-friendly cities initiative focuses mainly on the promotion of citizen participation as the key for its development. The Age-Friendly Cities and Communities are driven by the increased participation of citizens and the democratic commitment of the older people in the city (Moulaert and Garon 2016; Buffel and Phillipson 2018b).

According to Levasseur et al. (2010), there are six levels that can be organized into a taxonomy that orders and structures the different forms of social participation. The last level involves the interaction with other people, including society-oriented objectives and civic participation. These are voluntary activities that require an active and significant commitment, motivated by a desire for social change in tune with the choices expressed by society. In this sense, it contributes to transform the 
community into a better place to live and obtain a direct or indirect impact on the well-being of others (Universidad de Deusto 2013).

Citizen participation is understood as taking part in social and political decisions within a specific territorial framework and is based on the condition of citizenship. Citizenship is considered to be an exercise that is sustained by action (Arendt 1993) and is done on a daily basis, so the citizen is defined by his active role (Borja 2003). This is linked to the concept of governance, understood as the interaction of public administrations with civil society, not from the hierarchical but from the network relationship, to guarantee efficiency, quality, and good orientation of public policies (European Anti-Poverty Network EAPN). Following Lefebvre (1972), the notion of "right of the city" refers to one of the fundamental rights of the human being and citizenship, which implies the motivation of civil society to re-create the city as part of a common and collective 'mission' (Buffel et al. 2012; Costes 2011; Phillipson 2010). The citizen is the first manager of the city and its construction must be based on the satisfaction of the needs of citizens (Sierra 2015).

Nevertheless, the theories about social environments in old age have usually seen the individual as an adaptive recipient or user of social resources rather than as an active person who engages in the construction, or even production, of the social environment (Wahl and Lang 2004). In the AFCC project, older people are the protagonists and leaders of the action-research process.

In this sense, the methodology for the promotion of citizen participation in the project of AFCC is based on principles that are articulated in participatory action-research (PAR) approaches (OMS 2007). The PAR methodology provides institutions and human groups with a theoretical system and technical-practical tools to orient and integrate citizens' thinking and action (Marquez 2014). Thus, the intervention is aimed at both changing attitudes and increasing the repertoire of skills of the people, as well as looking for changes in the environment and patterns of interaction between these people and their environment. In addition, it seeks the development of a space of shared search and construction that gives new forms of interaction and social participation of people who are no longer considered "passive" or "dependent", but as "citizens" (Fantova 2001). In this way, it is intended to promote the participation of community members in the search for solutions to their problems and to help them to increase their control on relevant aspects of their lives, by raising power or empowering (Balcázar 2003). The ultimate PAR objective is to ensure that the community becomes the main agent of change to achieve the transformation of its reality.

Warth (2016, pp. 39-40) makes the point that the Age-Friendly process 'recommends a highly participatory approach that engages not only older people, but it also seeks alliances across government and with key stakeholders across all sectors of society'. Some models, such as those in Manchester (UK) and Quebec (Canada) and Basque Country (Euskadi Lagunkoia, Spain), have placed considerable emphasis on involving older people as the main actors in developing age-friendly communities. In Manchester, the researchers trained older residents to become co-investigators in a study that is aimed at developing the age-friendliness of neighborhoods. The co-researchers took a leading role in each phase of the study, from codesigning research objectives and conducting interviews with peers, to evaluating interventions (Buffel 2018b). In the Basque Country (Euskadi Lagunkoia), covering over 50 member municipalities, self-managed groups that are led by older people have been created. These groups design tours around the municipality with the aim of identifying local suggestions for improving the phsyical environment as well as developing solutions to the issues identified (Barrio 2014). Comparative research from other cities, including Portland, New York, and Brussels has also demonstrated the importance of partnerships (Buffel et al. 2014), including community participation, stakeholder involvement (Steels 2015), and 'relationships between the university and local city planning and government agencies' (Neal et al. 2014, p. 96) to achieve age-friendly goals.

\section{Discussion}

This paper reflects on the theory of Active aging, the changes in the roles assumed during the life course -mainly in the current generations of older people-, and the role of the AFCC project in this 
context. The paper gained insight on how these three events contributed the emergence of a citizen movement. With this the AFCC project can be a tool for older people to exercise their citizen role in search of a shared objective with other generations, to improve their city for all, moving forward from the concept of Active Aging to the active citizenship.

In the WHO's AFCC program, older people have an active role in contributing to the quality of life well-being in of different groups in cities (Sancho and Barrio 2010). For this, the protagonism and leadership is given to the citizens in general and to older people in particular, putting into practice the theory of Active aging by promoting the participation of people in social and political decision-making (Moulaert and Garon 2016; Barrio et al. 2016; Buffel and Phillipson 2018a).

Older people have the right to enjoy full citizenship and to actively participate in a comprehensive manner in society, claiming to be social subjects and rather than objects of attention and administration. This implies their presence in the social and political dynamics of their community, overcoming the barriers that have been built around Active Aging. These barries can distort the radical and transformative aim of Active Aging, by, for example, reducing the paradigm to issues, such as health, productive work, homogenization, or limited participation. The AFCC initiative may provide a useful response to these limitations by promoting social citizen participation, social co-responsibility, intergenerational relations, and communication, in order to improve the quality of life of all people. It can be seen as a tool for agingpromoting citizen participation for the common good of improving the city. In this way, it fits with the desire of current generation of older people and their desire to continue contribute to society in a variety of ways (Prieto et al. 2015; Subirats 2011). In this way, we can advance from the concept of Active Aging to Active citizenship.

The great social and political challenge regarding an aging population involves the recognition of older people's valuable contributions to society, by building upon their knowledge and experience, whilst at the same time tackling age discrimination and ageism. It is necessary to generate projects in favour of the community that are attractive to all generations, where age is not a differentiating or exclusive factor and where interests, concerns, and common objectives are shared. The challenge now is to move from an Age-Friendly movement to a friendly movement, promoting the idea of a city for all, irrespective of age. The movement for friendly environments is an attempt to move forward in this sense, by promoting citizen participation for all people, to generate enabling living environments for aging populations that increase well-being for all citizens. Doubtlessly, the well-known revolution of longevity, that forces us to abandon existing notions of old age and retirement (Kalache 2013; ILC 2015), poses important social and personal challenges to build a better, more egalitarian society capable of recognizing the value of each person regardless of their age and social, cultural or racial background.

Some limitations of the paper should be highlighted. First, while contributing to theoretical debates about Active Aging, more empirical evidence is needed in terms of understanding the processes that contribute to promoting active citizenship through Age-Friendly programmes. Second, it should also be noted that the AFCC project can be criticized for the same reasons as the concept of Active Aging (Biggs 2001; Bowling 2005; Hasmanová 2011), since in many cases it does not include diversity, fragility, and excluded groups of aging populations (Buffel and Phillipson 2018a). Thus, the goal of generating active citizenship similarly runs the risk of further empowering a more resourceful "elite" of older people, whilst adding to the exclusion of those that are already disadvantaged.

Despite these limitations, this paper has contributed novel ideas to the debate about Active Aging, by linking its historical and theoretical origins to the movement of Age-Friendliness, and combining these approaches with insights about the changing social context of older people. In conclusion, we hope this paper will help inspire new ways of thinking about Active Aging in the context of an active citizenship framework, one that recognizes the issue of diversity.

Author Contributions: All authors contributed to the analysis and writing for this paper.

Funding: This research received no external funding.

Conflicts of Interest: The authors declare no conflicts of interest. 


\section{References}

Alley, Dawn, Phoebe S. Liebig, Jon Pynoos, Tridib Banerjee, and In Hee Choi. 2007. Creating elder-friendly communities: Preparations for an aging society. Journal of Gerontological Social Work 49: 1-18. [CrossRef] [PubMed]

Arendt, Hannah. 1993. La Condición Humana. Barcelona: Piados.

Balcázar, Fabricio E. 2003. Investigación acción participativa (IAP): Aspectos conceptuales y dificultades de implementación. Fundamentos en Humanidades 4: 59-77.

Baltes, Paul B., and Margaret M. Baltes. 1990. Successful Ageing: A Psychosocial Perspectives. Cambridge: Cambridge University Press.

Bandura, Albert. 1986. Social Foundation of Thoughts and Actions. Upper Saddle River: Prentice Hall.

Barrio, Elena. 2014. Guía de implantación y uso en municipios: Euskadi Lagunkoia. Vitoria-Gasteiz: Departamento de Empleo Y Políticas Sociales-Gobierno Vasco.

Barrio, Elena. 2016. El ciclo de vida y el uso del tiempo. En M. Legarreta (Coord). In Dos décadas de cambio social en la C.A. de Euskadi a través del uso del tiempo. Encuesta de Presupuestos de Tiempo, 1993-2013. Monográfico. Donostia-San: EUSTAT-Euskal Estatistika Erakundea.

Barrio, Elena, Sacramento Pinazo, Alexandre Kalache, and Mayte Sancho. 2016. Ciudades y comunidades amigables con las personas mayores. In La visión territorial y sostenible del desarrollo local: Una perspectiva multidisciplinar. Edited by Joan Noguera. Valencia: Universitat de València, Servei de Publicacions, pp. 141-67.

Barusch, Amanda S. 2013. Age-friendly cities: A social work perspective. Journal of Gerontological Social Work 56: 465-72. [CrossRef] [PubMed]

Bass, Scott A., Francis G. Caro, Yung-Ping Chen, and Jill Norton. 1993. Achieving a Productive Aging Society. Westport: Auburn House.

Bauman, Zygmunt. 1999. Modernidad Líquida. Buenos Aires: Fondo de Cultura Económica.

Biggs, Simon. 2001. Toward a critical narrativity: Stories of aging in contemporary social policy. Journal of Aging Studies 15: 303-16. [CrossRef]

Blanco, Mauricio. 2010. Predictores psicosociales del envejecimiento activo: Evidencias en una muestra de personas adultas mayores. Anales en Gerontología 6: 11-29.

Borja, Jordi. 2003. La Ciudad Conquistada. Madrid: Alianza Editorial.

Boudiny, Kim. 2013. “Active ageing”: From empty rhetoric to effective policy tool. Ageing E Society 33: 1077-98. [CrossRef]

Boudiny, Kim, and Dimitri Mortelmans. 2011. A critical perspective: Towards a broader understanding of “active ageing". Electronic Journal of Applied Psychology 7: 8-14. [CrossRef]

Bowling, Ann. 2005. Ageing Well: Quality of Life in Old Age. Maidenhead: Open University Press.

Bowling, Ann. 2009. Perceptions of active ageing in Britain: Divergences between minority ethnic and whole population samples. Age and Ageing 38: 703-10. [CrossRef] [PubMed]

Buffel, Tine. 2018a. Co-production with older people. Researching age-friendly communities. Journal of Aging Studies 44: 52-60. [CrossRef] [PubMed]

Buffel, Tine. 2018b. Older co-researchers exploring age-friendly communities: An 'insider' perspective on the benefits and challenges of peer-research. The Gerontologist. [CrossRef] [PubMed]

Buffel, Tine, and Chris Phillipson. 2018a. A manifesto for the age-friendly movement: Developing a new urban agenda. Journal of Aging $\mathcal{E}$ Social Policy. [CrossRef]

Buffel, Tine, and Chris Phillipson, eds. 2018b. Age-Friendly Cities and Communities: A Global Perspective. Bristol: Policy Press.

Buffel, Tine, Chris Phillipson, and Thomas Scharf. 2012. Ageing in urban environments: Developing 'age-friendly' cities. Critical Social Policy 32: 597-617. [CrossRef]

Buffel, Tine, Paul McGarry, Chris Phillipson, Liesbeth De Donder, Sarah Dury, Nico De Witte, and An-Sofie Smetcoren. 2014. Developing age-friendly cities: Case studies from Brussels and Manchester and implications for policy and practice. Journal of Aging and Social Policy 26: 52-72. [CrossRef] [PubMed]

Buys, Laurie, and Evonne Miller. 2006. The meaning of "active ageing" to older Australians: Exploring the relative importance of health, participation and security. Paper presented at 39th Australian Association of Gerontology Conference, Sydney, Australia, 22-24 November. 
Caprara, Mariagiovanna, María Ángeles Molina, Rocío Schettini, Marta Santacreu, Teresa Orosa, Víctor Manuel Mendoza-Núñez, Macarena Rojas, and Rocío Fernández-Ballesteros. 2013. Active aging promotion: Results from the vital aging program. Current Gerontology and Geriatrics Research 2013: 14. [CrossRef] [PubMed]

Clarke, Amanda, and Lorna Warren. 2007. Hopes, fears and expectations about the future: what do older people's stories tell us about active ageing? Ageing E Society 27: 465-88. [CrossRef]

Costes, Laurence. 2011. Del ‘derecho a la ciudad' de Henri Lefebvre a la universalidad de la urbanización moderna. Urban NS02: 89-100.

Davey, Judith, Ganesh Nana, Virginia de Joux, and Mathew Arcus. 2004. Accommodation Options for Older People in Aotearoa/New Zealand. Wellington: Institute for Research on Ageing/Business \& Economic Research Ltd., for Centre for Housing Research Aotearoa/New Zealand.

van Dyk, Silke. 2014. The appraisal of difference: Critical gerontology and the active-ageing paradigm. Journal of Aging Studies 31: 93-103. [CrossRef] [PubMed]

European Anti-Poverty Network (EAPN). 2009. Guía metodológica de la participación social de las personas en situación de pobreza y exclusión social. Contributor, Red Europea de Lucha contra la Pobreza y la Exclusión Social en el Estado Español. Madrid: EAPN España, ISBN 8461356128, 9788461356126.

European Commission (EC). 1999. Towards a Europe for All Ages. Brussels: EC. Available online: http:/ / ec.europa. eu/employment_social/social_situation/docs/com221_en.pdf (accessed on 3 May 2018).

European Commission (EC). 2002. Europe's Response to World Ageing-Promoting Economic and Social Progress in an Ageing World: A Contribution of the European Commission to the 2nd World Assembly on Ageing. Brussels: EC.

European Commission (EC). 2018. Active Ageing. Available online: http://ec.europa.eu/social/main.jsp?catId= 1062\&langId=en (accessed on 5 May 2018).

Elder, Glen. 1974. Children of Great Depression: Social Change in Life Experience. Chicago: University of Chicago Press.

Fantova, Fernando. 2001. La gestión de organizaciones no lucrativas. Madrid: CCS.

Fernández-Ballesteros, Rocío. 2005. Evaluation of "Vital Ageing-M": A psychosocial programme for promoting optimal ageing. European Psychologists 10: 146-56. [CrossRef]

Fernández-Ballesteros, Rocío. 2008. Active Aging: The Contribution of Psychology. Gottingën: Hogrefe \& Huber.

Fernández-Ballesteros, Rocío, Elva-Dolores Arias, Marta Santacreu, and Neyda Rubalcava. 2011. Quality of Life in México and in Spain. In The Global Dynamics of Aging. Edited by Jason L. Powell. New York: Nova Science Publisher Inc.

Fernández-Mayoralas, Gloria, Fermina Rojo-Pérez, Pablo Martínez-Martín, María-Eugenia Prieto-Flores, Carmen Rodríguez-Blázquez, Salomé Martín-García, José Manuel Rojo-Abuín, and María-Joao Forjaz. 2015. Active ageing and quality of life: Factors associated with participation in leisure activities among institutionalized older adults, with and without dementia. Aging E Mental Health 19: 1031-41. [CrossRef]

Fitzgerald, Kelly, and Francis Caro. 2014. An Overview of Age-Friendly Cities and Communities around the World. Journal of Aging $\mathcal{E}$ Social Policy 26: 1-18. [CrossRef]

Fitzgerald, Kelly G., and Francis G. Caro, eds. 2016. International Perspectives on Age-Friendly Cities. New York: Routledge.

Foster, Liam, and Alan Walker. 2013. Gender and active ageing in Europe. European Journal of Ageing 10: 3-10. [CrossRef] [PubMed]

Foster, Liam, and Alan Walker. 2015. Active and Successful Aging: A European Policy Perspective. The Gerontologist 55: 83-90. [CrossRef] [PubMed]

Gilleard, Chris. 2005. Cultural approaches to the ageing body. In The Cambridge Handbook of Age and Ageing. Cambridge: Cambridge University Press.

Golant, Stephen M. 2014. Age-Friendly Communities: Are We Expecting Too Much? Montreal: Institute for Research on Public Policy, p. 2.

Guillemard, Anne Marie. 1992. Análisis de las políticas de vejez en Europa. Madrid: Ministerio de Asuntos Sociales.

Hasmanová, Jaroslava. 2011. Leisure in old age: Disciplinary practices surrounding the discourse of active ageing. International Journal of Ageing and Later Life 6: 5-32. [CrossRef]

Havighurst, Robert J. 1961. Successful aging. The Gerontologist 1: 8-13. [CrossRef]

Heumann, Leonard, and Duncan Bold. 1993. Aging in Place with Dignity: International Solutions to the Low-Income and Frail Elderly. London: Praeger. 
Holstein, Martha B., and Meredith Minkler. 2003. Self, society, and the "new gerontology". The Gerontologist 43: 787-96. [CrossRef] [PubMed]

Holstein, Martha B., and Meredith Minkler. 2007. Critical gerontology: Reflections for the 21st century. In Critical Perspectives on Ageing Societies. Edited by Miriam Bernard and Tomas Scharf. Cambridge: Polity Press, pp. 13-26.

International Longevity Centre Brazil (ILC). 2015. Active Ageing: A Policy Framework in Response to the Longevity Revolution. Rio de Janeiro: International Longevity Centre Brazil.

Kalache, Alexandre. 1999. Active ageing makes the difference. Bulletin of the World Health Organization 77: 299. [CrossRef] [PubMed]

Kalache, Alexandre. 2013. The Longevity Revolution: Creating a Society for All Ages. Adeleide Thinker in Residence 2012-2013. Adeleide: Government of South Australia.

Kalache, Alexandre. 2016. Active ageing and age-friendly cities-A personal account. In Age-Friendly Cities and Communities in International Comparison. Edited by Thibauld Moulaert and Suzanne Garon. Cham: Springer, pp. 65-77.

Kalache, Alexandre, and Ingrid Kickbusch. 1997. A global strategy for healthy ageing. World Health 4: 4-5.

Katz, Stephen. 2000. Busy Bodies: Activity, aging, and the management of everyday life. Journal of Aging Studies 14: 135-52. [CrossRef]

Katz, Stephen. 2005. Cultural Aging: Life Course, Lifestyle and Senior Worlds. Peterborough: Broadview Press.

Komp, Kathrin, and Stina Johansson. 2016. Population ageing in a lifecourse perspective: Developing a conceptual framework. Ageing and Society 36: 1937-60. [CrossRef]

Lassen, Aske Juul, and Tiago Moreira. 2014. Unmaking old age: Political and cognitive formats of active ageing. Journal of Aging Studies 30: 33-46. [CrossRef] [PubMed]

Lefebvre, Henri. 1972. La revolución urbana. Madrid: Alianza.

Levasseur, Mélanie, Lucie Richard, Lise Gauvin, and Émilie Raymond. 2010. Inventory and analysis of definitions of social participation found in the aging literature: Proposed taxonomy of social activities. Social Sciences and Medicine 71: 2141-49. [CrossRef] [PubMed]

Liddle, Jennifer, Thomas Schartf, Bernadette Bartlam, Miriam Bernard, and Julius Sim. 2014. Exploring the age-friendliness of purpose-built retirement communities: Evidence from England. Ageing and Society 34: 1601-29. [CrossRef]

Lui, Chi-Wai, Jo-Anne Everingham, Jeni Warburton, Michael Cuthill, and Helen Bartlett. 2009. What makes a community age-friendly: A review of international literature. Australasian Journal on Ageing 28: 116-21. [CrossRef] [PubMed]

Van Malderen, Lien, Tony Mets, Patricia De Vriendt, and Ellen Gorus. 2013. The Active Ageing-concept translated to the residential long-term care. Quality of Life Research 22: 929-37. [CrossRef] [PubMed]

Marquez, Mar. 2014. Una metodología para pensar la ciudad. In Pensar la ciudad. Nuevas herramientas para la regeneración urbana. Edited by Nuria Nebot, Miguel González and Raúl Fernández. Málaga: Ayuntamiento de Málaga.

Marsillas, Sara. 2016. Desarrollo y validación de un Índice Personal de Envejecimiento Activo adaptado al contexto gallego. Ph.D. thesis, Universidad de Santiago de Compostela, Santiago de Compostela, Spain.

Marsillas, Sara, Liesbeth De Donder, Martin Kardol, Sofie van Regenmortel, Sarah Dury, Dorien Brosens, and Jesús Varela. 2017. Does active ageing contribute to life satisfaction for older people? Testing a new model of active ageing. European Journal of Ageing 14: 295-310. [CrossRef] [PubMed]

Mendes, Felismina Rosa. 2013. Active ageing: A right or a duty? Health Sociology Review 22: 174-85. [CrossRef]

Moulaert, Thibauld, and Suzanne Garon, eds. 2016. Introduction: Toward a Better Understanding of AFCC. In Age-Friendly Cities and Communities in International Comparison. London: Springer, vol. 14.

Moulaert, Thibauld, and Mario Paris. 2013. Social policy on ageing: The case of "Active Ageing" as a theatrical metaphor. International Journal of Social Science Studies 1: 113-23. [CrossRef]

Neal, Margaret B., Alan K. DeLaTorre, and Paula C. Carder. 2014. Age-Friendly Portland: A university-citycommunity partnership. Journal of Aging \& Social Policy 26: 88-101.

Neugarten, Bernice L. 1968. Middle Age and Aging: A Reader in Social Psychology. Chicago: University of Chicago Press.

Organización Mundial de la Salud (OMS). 2007. Guia: Ciudades Globales Amigables con los mayores. Ginebra: OMS. 
Paúl, Constança, Oscar Ribeiro, and Laetitia Teixeira. 2012. Active ageing: An empirical approach to the WHO model. Current Gerontology and Geriatrics Research 2012: 10. [CrossRef] [PubMed]

Pavlova, Maria K., and Rainer K. Silbereisen. 2012. Perceived level and appraisal of the growing expectations for active ageing among the young-old in Germany. Research on Aging 34: 80-99. [CrossRef]

Perek-Białas, Jolanta, Anna Ruzik, and Lucie Vidovićová. 2008. Active ageing policies in the Czech Republic and Poland. International Social Science Journal 58: 559-70. [CrossRef]

Phillipson, Chris. 2010. Ageing and Urban Society: Growing Old in the "Century of the City". In The SAGE Handbook of Social Gerontology. Edited by Chris Phillipson and Dale Dannefer. London and New York: Sage Publications Ltd., pp. 597-606.

Plouffe, Louise, and Alexandre Kalache. 2010. Towards global Age-Friendly cities: Determining urban features that promote active aging. Journal of Urban Health: Bulletin of the New York Academy of Medicine 87: 733-39. [CrossRef] [PubMed]

Prieto, Daniel, Diego Herranz, and Pilar Rodriguez. 2015. Envejecer si ser Mayor. Madrid: Fundación Pilares para la Autonomía Personal.

Pruchno, Rachel A., Maureen Wilson-Genderson, Miriam Rose, and Francine Cartwright. 2010. Successful aging: Early influences and contemporary characteristics. The Gerontologist 50: 821-33. [CrossRef] [PubMed]

Ranzijn, Rob. 2010. Active ageing-Another way to oppress marginalized and disadvantaged elders?: Aboriginal Elders as a case study. Journal of Health Psychology 15: 716-23. [CrossRef] [PubMed]

Rémillard-Boilard, Samuèle, Tine Buffel, and Chirs Phillipson. 2017. Involving older residents in age-friendly developments: From information to co-production mechanisms. Journal of Housing for the Elderly 31: 146-59. [CrossRef]

Rowe, Jhon W., and Robert L. Kahn. 1998. Successful Aging. New York: Pantheon.

Rowles, Graham D. 1993. Evolving images of place in ageing and 'aging in place'. Generations 17: 65-70.

Sancho, Mayte, and Elena Barrio. 2010. Donostia-San Sebastián, ejemplo de ciudad amigable. La ciudad y los mayores. Barcelona Metrópolis: Revista de información y pensamiento urbanos 80: 58-62.

Scharlach, Andrew E., and Amanda J. Lehning. 2013. Ageing-friendly communities and social inclusion in the United States of America. Ageing \& Society 33: 110-36.

Seguí-Cosme, Salvador, and Alfredo Alfageme. 2008. El retiro temporal a lo largo de la vida: Bases sociológicas y filosóficas. In Modernidad, crisis y globalización: Problemas de política y cultura. Edited by Victor Pérez-Díaz. Colección Mediterráneo Económico N14. Almería: Caja Rural Intermediterránea, Cajamar.

Sidorenko, Alexandre, and Asghar Zaidi. 2013. Active ageing in CIS countries: Semantics, challenges, and responses. Current Gerontology and Geriatrics Research 2013: 17. [CrossRef] [PubMed]

Sierra, Isabel. 2015. Ciudades para las personas: Escenarios de vida. Madrid: Ediciones Díaz de Santos.

Steels, Stephanie. 2015. Key characteristics of age-friendly cities and communities: A review. Cities 47: 45-52. [CrossRef]

Stenner, Paul, Tara McFarquhar, and Ann Bowling. 2011. Older people and "active ageing": Subjective aspects of ageing actively. Journal of Health Psychology 16: 467-77. [CrossRef] [PubMed]

Strawbridge, William J., Margaret I. Wallhagen, and Richard D. Cohen. 2002. Rowe and Kahn Successful Aging Measure. The Gerontologist 42: 727-33. [CrossRef] [PubMed]

Subirats, Joan. 2011. Ciudadanía y personas mayores. In Libro blanco Envejecimiento Activo. Edited by Purificación Causapié, Antonio Balbontin, Manuel Porras and Adela Mateo. Madrid: Instituto de Mayores y Servicios Sociales (IMSERSO).

Subirats, Joan. 2016. Cambio de época y personas mayores. Una concepción de ciudadanía abierta e inclusiva. In Edades en transición. Envejecer en el siglo XXI. Edades, condiciones de vida, participación e incorporación tecnológica en el cambio de época. Edited by Sandra Ezquerra, Mercè Pérez, Margarita Pla and Joan Subirats. Barcelona: Editorial Ariel.

Townsend, Jean, Mary Godfrey, and Tracy Denby. 2006. Heroine, villains and victims: Older people's perceptions of others. Ageing \& Society 26: 883-900. [CrossRef]

United Nations (UN). 2011. World Population Ageing: Profiles of Ageing 2011. CD-ROM. New York: United Nations. United Nations (UN). 2017. World Population Prospects: The 2017 Revision. New York: Department of Economic and Social Affairs, Population Division. 
Universidad de Deusto. 2013. Un proyecto de investigación-acción participativa con personas mayores de Bizkaia en el ámbito del empoderamiento personal y comunitario (participación ciudadana). Bilbao: Universidad de Deusto, Equipo de Investigación en Gerontología, BizkaiLab.

Venn, Susan, and Sara Arber. 2011. Day-time sleep and active ageing in later life. Ageing E Society 31: 197-216. [CrossRef]

Wahl, Hans-Werner, and Frieder R. Lang. 2004. Aging in context across the adult life: Integrating physical and social research perspectives. In Aging in Context: Socio-Physical Environments. Edited by Hans-Werner Wahl, Rick J. Scheidt and Paul G. Windley. New York: Springer, pp. 1-33.

Wahl, Hans-Werner, Agneta Fange, Frank Oswald, Laura N. Gitlin, and Susanne Iwarsson. 2009. The home environment and disability-related outcomes in aging individuals: What is the empirical evidence? The Gerontologist 49: 355-67. [CrossRef] [PubMed]

Walker, Alan. 2002. A strategy for active ageing. International Social Security Review 55: 121-39. [CrossRef]

Walker, Alan. 2009. The emergence and application of active aging in Europe. Journal of Aging E Social Policy 21: 75-93. [CrossRef]

Walker, Alan. 2016. Population Ageing from Global and Theoretical Perspective: European Lessons on Active Ageing. In Age-Friendly Cities and Communities in International Comparison. Political Lessons, Scientific Avenues, and Democratic Issues. Edited by Thibauld Molutaert and Suzanne Garon. Berlin: Springer.

Walker, Alan, and Tony Maltby. 2012. Active ageing: A strategic policy solution to demographic ageing in the European Union. International Journal of Social Welfare 21: 117-30. [CrossRef]

Warth, Lisa. 2016. The WHO Global Network of Age-Friendly Cities and Communities: Origins, Developments and Challenges. In Age-Friendly Cities and Communities in International Comparison. International Perspectives on Aging. Edited by Thibauld Moulaert and Suzanne Garon. Cham: Springer.

World Health Organization (WHO). 1990. Healthy Ageing. Geneva: World Health Organization.

World Health Organisation (WHO). 2002. Active Ageing: A Policy Framework. Geneva: World Health Organization.

World Health Organization (WHO). 2004. Towards Age-Friendly Primary Health Care. Geneva: World Health Organization.

World Health Organization (WHO). 2007. Vancouver Protocol. Geneva: World Health Organization.

World Health Organization (WHO). 2014. Global Network of Age-Friendly Cities and Communities. Geneva: World Health Organization. Available online: http:/ / www.who.int/ageing/projects/age_friendly_cities_network/en/ (accessed on 5 May 2018).

World Health Organization (WHO). 2015. World Report on Ageing and Health. Geneva: World Health Organization. World Health Organization (WHO). 2017. Membership Documents. Adhesión a la Red Mundial de Ciudades y Comunidades Amigables con las Personas Mayores (GNAFCC). Available online: http: / www.who.int/ ageing/age-friendly-environments/GNAFCC-membership-es.pdf (accessed on 5 May 2018).

World Health Organization (WHO). 2018. Global Network of Age-Friendly Cities and Communities. Geneva: World Health Organization. Available online: https:/ / extranet.who.int/agefriendlyworld/who-network/ (accessed on 5 May 2018).

Williams, Simon J., Paul Higgs, and Stephen Katz. 2012. Neuroculture, active ageing and the "older brain": Problems, promises and prospects. Sociology of Health and Illness 34: 64-78. [CrossRef] [PubMed]

Zaidi, Asghar, Katrin Gasior, Maria Hofmarcher, Orsolya Lelkes, Bernd Marin, Ricardo Rodrigues, Andrea Schmidt, Pieter Vanhuysse, and Eszter Zolyomi. 2013. Active Aging Index 2012: Concept, Methodology and Final Results. Vienna: European Centre Vienna.

(C) 2018 by the authors. Licensee MDPI, Basel, Switzerland. This article is an open access article distributed under the terms and conditions of the Creative Commons Attribution (CC BY) license (http://creativecommons.org/licenses/by/4.0/). 